\title{
"Crop-Life" Does Not Slow Postharvest Drying of Fraser Fir and Eastern Red Cedar Christmas Trees
}

\author{
L.E. Hinesley ${ }^{1}$ and L.K. Snelling ${ }^{2}$ \\ Department of Horticultural Science, Box 7609, North Carolina State \\ University, Raleigh, NC 27695-7609
}

\author{
Scott Goodman ${ }^{2}$ \\ Mountain Research Station, 516 Test Farm Road, Waynesville, \\ NC 28786-40160
}

Additional index words. Abies fraseri, Juniperus virginiana, antitranspirant

Fraser fir [Abies fraseri (Pursh) Poir.] is a desirable Christmas tree species that is grown in western North Carolina and other states. We are unaware of any reports concerning antitranspirants and postharvest drying of Fraser fir. Eastern red cedar (Juniperus virginiana L.) is commonly used as a Christmas tree throughout its range in the eastern United States. Red cedar, if displayed without water, dries extremely fast, even when coated with latex colorants (Hinesley, 1990).

Our objective was to determine the effect of Crop-Life (Polymer Technologies, Nocatee, Fla.), an acrylic polymer that supposedly "retards evapotranspiration (water-loss)," on drying of Fraser fir and eastern red cedar.

Drying Fraser fir and eastern red cedar branches in a controlled environment (Expt. 1). On 1 Feb. 1990, two uniform branch tips $(0.5 \mathrm{~m}$ long) were collected from each of six Fraser firs, and their bases were immediately placed in water. Branches were transported to Raleigh and stored at 5C. Similar branch pairs were collected (2 Feb. 1990) from six eastern red cedar Christmas trees in Raleigh. They were also placed in water and stored at $5 \mathrm{C}$.

Received for publication 18 Feb. 1993. Accepted for publication 12 June 1993. This research was funded by the North Carolina Agricultural Research Service (NCARS), Raleigh, NC 27695-7643. Use of trade names in this publication does not imply endorsement by the NCARS of products named nor criticism of similar ones not mentioned. The cost of publishing this paper was defrayed in part by the payment of page charges. Under postal regulations, this paper therefore must be hereby marked advertisement solely to indicate this fact.

'Professor.

${ }^{2}$ Research Technician.
On 3 Feb. 1990, one branch from each pair was thoroughly coated with Crop-Life (concentration 1:20), using a backpack sprayer. Branches, which were held in water, were sprayed, and their surfaces were allowed to dry in the sun for $\approx 15 \mathrm{~min}$. After drying, xylem pressure potential $(\psi)$ was measured on one branch from each tree, using a pressure bomb (PMS Instruments, Corvallis, Ore.). Branches were removed from water, their fresh weight recorded, and placed in a dark growth chamber $(20 \mathrm{C}, 60 \%$ relative humidity). Weight and $\psi$ were taken after 2 days for red cedar and 7 days for Fraser fir. Treatment means were compared by $t$ tests $(P \leq 0.05)$.

Drying Fraser fir Christmas trees kept outdoors (Expt. 2). On 7 Oct. 1992, eight Fraser fir Christmas trees growing at the Mountain Research Station in Waynesville, N.C., were thoroughly coated with Crop-Life (concentration 1:20), using a backpack sprayer equipped with a TeeJet 8002 flat fan nozzle (Spraying Systems Co., Wheaton, Ill.). Each tree was sprayed with $\approx 1.2$ liters of mixture. Eight nontreated trees were kept as controls. Outside temperature was $13 \mathrm{C}$, with a clear sky and light wind.

The 16 trees were cut and baled the afternoon of 9 Nov. 1992, and immediately moved to a nearby gravel parking lot. Initial $\psi$ was determined on four Crop-Life trees and four nonsprayed trees. Fresh weight was measured for each tree, and ranged from 25 to $34 \mathrm{~kg}$. Trees were laid horizontally on an unprotected outdoor bench, $\approx 0.5 \mathrm{~m}$ above ground. There was good air circulation around each tree.

The experiment ended on 30 Nov. 1992. Fresh weight and $\psi$ were recorded for each tree. Each tree was dropped several times (butt first) onto a concrete sidewalk from a height of $\approx 0.5 \mathrm{~m}$, and dislodged needles were collected and weighed. Treatment means were compared by $t$ tests $(P \leq 0.05)$.

Crop-Life had no significant effect on the $\psi$ of either species in Expt. 1 (difference between control and treated trees: 0.4 and 0.1 $\mathrm{MPa}$ for Fraser fir and red cedar, respectively). Red cedar dried to $-4 \mathrm{MPa}$ in 2 days compared to $\approx 7$ days for Fraser fir. A $\psi$ of $-4 \mathrm{MPa}$ is close to the critical moisture content [the moisture level below which a tree will not fully rehydrate when the base is recut and placed in water (Van Wagner, 1963)] for both species (Hinesley, 1984, 1988).

In Expt. 2, $\psi$ initially was -0.8 and -0.9 $\mathrm{MPa}$ for control and treated trees, respectively. On the second day after harvest, $\psi$ averaged $-1.9 \mathrm{MPa}$ for control trees and -2.1 MPa for trees coated with Crop-Life. Each tree lost $\approx 1 \mathrm{~kg}$ of water. After 3 weeks, the effect of Crop-Life remained nonsignificant (-3.0 MPa, Crop-Life; -2.9 MPa, control). By this time, water loss averaged $16 \%$ of initial fresh weight. Needle drop and foliage color were not adversely affected by treatment (data not presented).

We do not know the reason for the ineffectiveness of Crop-Life in preventing drying. Experiments with Douglas fir have yielded few positive results even when trees were completely dipped into tanks containing antitranspirant solutions (Montano and Proebsting, 1986). In our experiments, it is unlikely that the material washed off the foliage. Branches in Expt. 1 received no additional wetting after they were sprayed with Crop-Life. Trees in Expt. 2 received $70 \mathrm{~mm}$ of rain between 7 Oct. and 9 Nov. 1992. The product label says that 160 to $250 \mathrm{~mm}$ of rain is required to remove the material from foliage.

\section{Literature Cited}

Hinesley, L.E. 1984. Measuring freshness of cut Fraser fir Christmas trees. HortScience 19:860862.

Hinesley, L.E. 1988. Water relations of cut eastern red cedar Christmas trees. HortScience 23:589591.

Hinesley, L.E. 1990. Latex colorant slows drying of red cedar Christmas trees. HortScience 25:673674.

Montano, J.M. and W.M. Proebsting. 1986. Storage of cut Douglas fir: Relationship to the damage threshold. HortScience 21:1174-1175.

Van Wagner, C.E. 1963. Flammability of Christmas trees. Dept. of Forestry Publ. 1034, Ottawa, Canada. 